\title{
Shadow banking in China compared to other countries
}

\author{
Franklin Allen $^{1}$ | Xian $\mathbf{G u}^{2,3}$
}

${ }^{1}$ Imperial College Business School, Imperial College London, London, UK

${ }^{2}$ Durham University Business School, Durham University, Durham, UK

${ }^{3}$ Central University of Finance and Economics, Beijing, China

\section{Correspondence}

Franklin Allen, Imperial College Business School, Imperial College London, Tanaka Building, London, SW7 2AZ, UK.

Email: f.allen@imperial.ac.uk

\begin{abstract}
China's shadow banking has been rising rapidly in the last decade, mainly driven by regulations for banks, the Fiscal Stimulus Plan in 2008 and credit constraints in restrictive industries. This sector has continued growing although the regulators repeatedly attempted to impose new regulations on banks and nonbanks. The existence of shadow banking fulfills the high demand for funding. The standard view is that it poses risks to financial stability. However, in China, this is not necessarily the case. Entrusted loans, implicit guarantees from nonbanks, banks or government may provide a second-best arrangement in funding risky projects and improving welfare.
\end{abstract}

\section{K E Y W O R D S}

credit constraint, financial stability, implicit guarantee, regulation, shadow banking

J EL CLASS I F I C A T I O N

G20; G21; G23; G28

\section{1 | INTRODUCTION}

China's shadow banking has been growing significantly in the last decade. The increasing sophistication of the financial system can be both a blessing and a curse. While corporations and households benefit from the rapidly growing shadow banking as an alternative funding channel, regulators face challenges of maintaining financial stability in a more complex market. The fundamental questions are how the shadow banking system of China, the largest economy in the world in Purchasing Power Parity terms, relates to its economic growth and whether the shadow banking amplifies or reduces 
systemic risk. It is also important to know how the structure of China's shadow banking is different from that in other jurisdictions around the world.

The literature on China's shadow banking has also been actively growing in recent years. This paper aims to discuss the emergence, growth and components of China's shadow banking, provide a comparison with the counterparts in the United States, the United Kingdom and Europe and review the recent literature. In Section 2, we review the connections between banks and shadow banks in China and then explore the structure of China's shadow banking. We consider how it has been able to grow under light regulations and then discuss the risks embedded in this sector as well as the role of government. Section 3 compares China's shadow banking with that in other places. Section 4 concludes.

\section{2 | SHADOW BANKING IN CHINA}

\subsection{Banks and the rise of shadow banking}

China's financial system has been dominated by a state-owned banking system. A large literature has documented that the government supports the state-owned sector much more than the private sector by granting large-scale bank loans through the traditional commercial banks (e.g., Brandt \& Zhu, 2000; Cong, Gao, Ponticelli, \& Yang, 2019). Therefore, a natural question is how the private sector has been able to develop without sufficient access to finance over time. Allen, Qian, and Qian (2005) argue that an alternative financial sector including informal financing, built on trust, relationship and reputation, has played an important role in supporting the growth of a private sector that has been growing much faster than both the state sector and the listed sector. In recent years, in addition to informal financing, nonbank financial institutions and shadow banking have provided significant financing for growth for this sector.

Shadow banking is broadly defined as credit intermediation that occurs through activities and entities outside the regulated financial system (Adrian \& Ashcraft, 2012). In China, the activities component of shadow banking includes the issuance by a variety of institutions of wealth management products (WMPs), asset management products (AMPs), entrusted loans, trust loans, undiscounted bankers' acceptance, finance company loans, microcredit by, peer-to-peer (P2P) lending and informal lending. Examples of shadow banking entities are trust companies, broker dealers, P2P platforms and so forth.

Figure 1 shows the breakdown of total social financing and the size of different sources of funding in China. ${ }^{1}$ Funding from banks includes bank loans in local and foreign currencies through the traditional banking system; shadow banking funding includes entrusted loans, trust loans, undiscounted banker's acceptance, informal lending and others; funding from markets include capital raised through both equity and bond markets. From 2002 to 2019, on average, bank loans constitute $72.5 \%$ of the total social financing, with shadow banking and markets contributing $18.5 \%$ and $8.9 \%$, respectively. Since 2009, the shadow banking sector has experienced tremendous growth, reaching $32.9 \%$ of the total financing in 2016.

The reasons behind the fast growth include liquidity regulation, the Stimulus Plan launched in 2008, as well as credit constraints in certain industries. Hachem and Song (2017) document that one of the main causes of Chinese shadow banking growth was regulatory arbitrage of liquidity rules, in

\footnotetext{
${ }^{1}$ Total social financing, a term defined by the People's Bank of China (PBoC), refers to the total funds the real economy obtained from the financial system over a certain period of time. It measures money offered by domestic suppliers, including financial institutions, households and nonfinancial corporations and entities. For more details, please see, Allen, Qian and Gu (2017).
} 


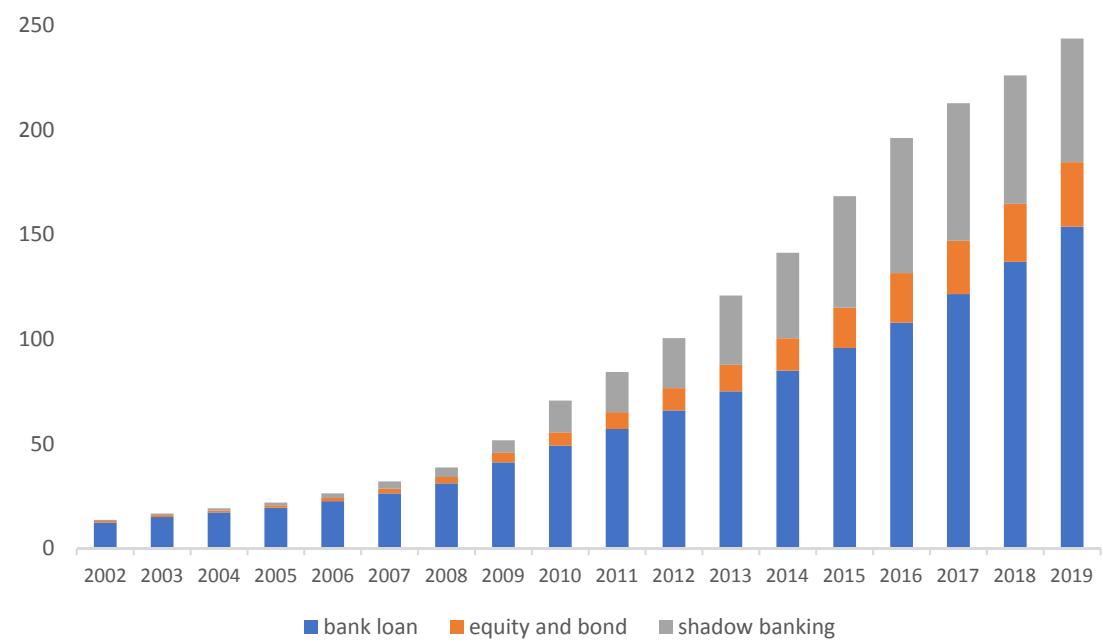

F I G U RE 1 Breakdown of total social financing in China: banks, shadow banks and markets. This figure plots the breakdown of total social financing (i.e., the sources of funding from banks, shadow banks and markets) in China. Funding from banks include bank loans in local currency (RMB) and foreign currencies; funding from shadow banks include entrusted loans and trust loans, and others; funding from the markets contains capital raising through equity and bond markets. Defined by the PBoC, total social financing covers loans in the local currency, loans in foreign currency, entrusted loans, trust loans, undiscounted bankers' acceptances, corporate bond financing and equity financing for nonfinancial corporations. Source: PBoC; Moody's [Colour figure can be viewed at wileyonlinelibrary. com]

particular, the $75 \%$ cap on the loan-to-deposit ratio (LDR). In August 2010, the China Banking Regulatory Commission (CBRC) announced that WMPs issued by banks could invest at most $30 \%$ in trust loans in order to reduce the links between banks and trust companies. In March 2013, the CBRC announced that WMPs could invest at most 35\% in non-standard debt assets (including trust assets). ${ }^{2}$ This change led to rapid growth in a new instrument called trust beneficiary rights to help channel WMP funds to trust companies. ${ }^{3}$ Several other studies also link the rise of shadow banking to the Fourtrillion Fiscal Stimulus Plan in 2008. Using provincial and city-level data, Chen, He, and Liu (2020) show that the upsurge of shadow banking is driven by the high financing demand in certain industries, triggered specifically by the Four-Trillion Fiscal Stimulus Plan in 2008. Acharya, Qian, Su, and Yang (2019) explain the growth of bank WMPs and find that the competition in the deposit market intensified

\footnotetext{
${ }^{2}$ Non-standard debt asset, is a term defined by the CBRC as a debt instrument that is not traded in the interbank bond market or stock exchange. As such, it includes instruments such as trust loans, various types of beneficiary rights, bankers' acceptance, letters of credit, accounts receivables and equity financing under repurchase agreements. The annual reports of China Bank Wealth Management Products give details of investments of bank WMPs. The report of 2018 (in Chinese) is available at: https://www.chinawealth.com.cn/resource/830/846/863/51198/52005/3018253/1553843656668154934893.pdf.

${ }^{3}$ There have been various regulations on shadow banking in this period. For example, in 2013, the State Council, in Order 107, identifies the agencies responsible for different supervisory tasks: the State Council, CBRC, CSRC (China Securities Regulatory Commission), CIRC (China Insurance Regulatory Commission) and the PBoC. For more details, please see: General Office of the State Council of the People's Republic of China, Notice of the General Office of the State Council on Issues Concerning Strengthening the Supervision of Shadow banking, December 31, 2013. This Order distinguished between credit intermediaries with and without financial licenses.
} 


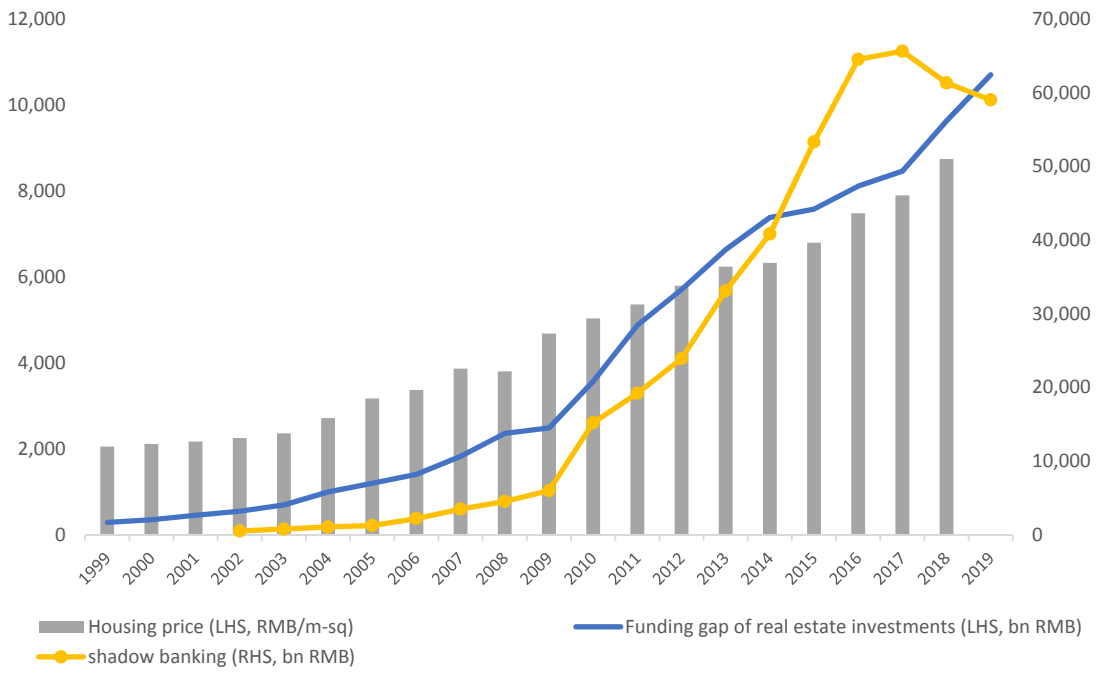

F I G URE 2 Housing price, funding gap of real estate investments and shadow banking activities. This figure plots the national average housing price, the funding gap of real estate investments (the difference between real estate investments and bank loans flowing to real estate), as well as the total shadow banking activities. The data of housing price and real estate investments come from the National Bureau of Statistics of China; the data of bank loans to real estate come from the PBoC; the data of shadow banking come from the PBoC and Moody's. Source: National Bureau of Statistics; PBoC; Moody's [Colour figure can be viewed at wileyonlinelibrary.com]

following the stimulus plan in 2008 and consequently, banks facing a short-fall in deposits, especially small and medium-sized banks, issue more WMPs to attract funding. Hachem (2018) argues that regulatory arbitrage is a more compelling explanation of the fast rise of shadow banking than Fiscal Stimulus. In addition, as a supplement to traditional monetary policy tools, the People's Bank of China (PBoC), the central bank of China, imposes loan quotas to commercial banks in some restrictive areas (e.g., the real estate industry and industries with overcapacity) through window guidance. ${ }^{4}$ Because of the strict regulation on lending to the real estate industry and to local government financing platforms, there has been a large gap between the financing demand and bank loans in these areas (Allen, Gu, Li, Qian, \& Qian, 2020; Allen, Gu, \& Qian, 2018). Figure 2 shows that the funding gap of real estate investments (the difference between real estate investments and bank loans to real estate) has increased significantly in the last decade, along with the growth of shadow banking. Consistently, both Allen, Qian, Tu, and Yu (2019) and Allen et al. (2020) document that the majority of the funds raised through nonaffiliated entrusted loans and trust products have flowed to the real estate and infrastructure industries. Wang, Wang, Wang, and Zhou (2019) document that the shadow banking sector in China channels the funds to capital-deprived and high-productivity private firms and reduces capital idleness.

\section{$2.2 \quad$ Structure of shadow banking}

Figure 3 shows how the components of China's shadow banking sector evolve from 2010 to 2019. On average, the largest component is assets funded by bank WMPs or AMPs of broker-dealer firms,

${ }^{4}$ Please see Section 2.2 for more discussion about the window guidance by the PBoC. 
70

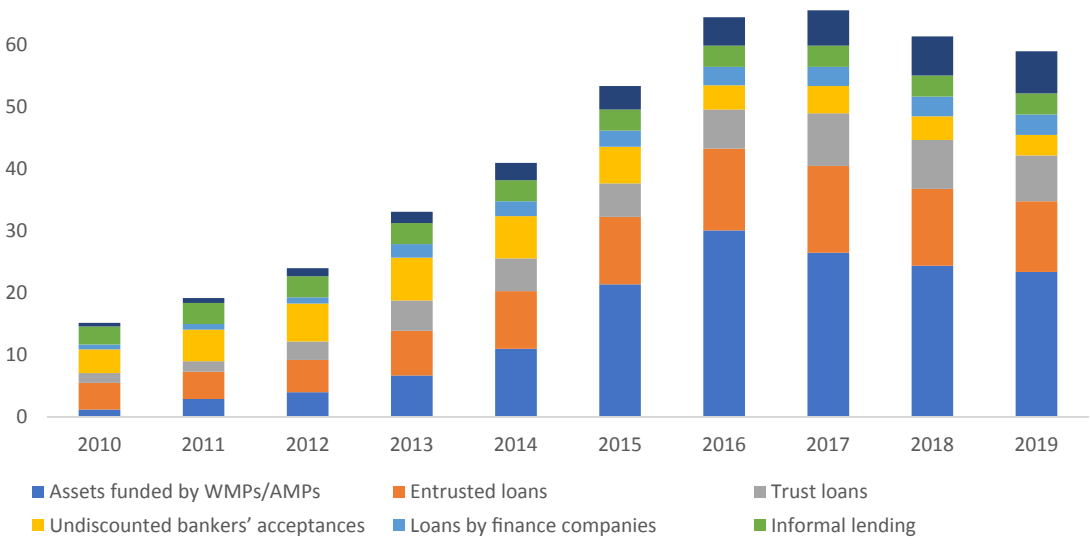

F IG URE 3 Components of shadow banking in China. This figure plots the size of the components of shadow banking in China from 2010 to 2019. The data come from the Quarterly China Shadow Banking Monitor by Moody's (March 2020): https://www.moodys.com/researchdocumentcontentpage.aspx?docid=PBC_1220469. The original sources include People Bank of China (PBoC); China Banking Wealth Management Product Registration \& Depository Center; Asset Management Association of China; WIND; Ministry of Commerce; China Leasing Alliance; China Financing Guarantee Association. Note that for 'informal lending', it is assumed there is no change from the end of 2011, sourced from a survey by the PBoC in May 2011 of 6,615 corporate borrowers. 'Others' includes financial leasing, microcredit, pawn shop loans, online peer-to-peer lending, asset-based securities and consumer credit companies. Source: Moody's [Colour figure can be viewed at wileyonlinelibrary.com]

constituting $29.4 \%$ of the total shadow banking assets, followed by entrusted loans, undiscounted bankers' acceptance and trust loans. In addition, these components are usually taken as core shadow banking assets, while the broader concept of shadow banking also contains loans by finance companies, informal lending and others, (Moody's, 2020).

Bank WMPs are off-balance-sheet investment products issued by banks as substitutes for deposits to circumvent liquidity regulations, raise funds and increase profits. Interest rates were tightly regulated in China before the lifting of the upper bound on deposits rates in 2015. However, interest rates on bank WMPs are much less regulated than deposit rates and the raised funds via these products are invested in projects without affecting issuing banks' on-balance sheet assets (Acharya et al., 2019). The size of bank WMPs began to take off in 2011 and the balance reached 32.10 trillion RMB by 2018. Majority bank WMP funds flowed to the bond market. For example, in 2018, 53.4\% of bank WMP funds flowed to the bond market, followed by $17.2 \%$ invested in non-standard debt assets (including trust assets) and $9.9 \%$ invested in equity related assets.

Undiscounted bankers' acceptances (BAs) are short-term debt instruments issued by a company with trade credit guaranteed by a bank. As long as the company does not need to fall back on this guarantee, these instruments are undiscounted and hence treated as off-balance-sheet items of the issuing bank. If the company cannot repay the third party and this party needs to cash in on the bank's guarantee, then the guarantee is discounted and appears on the balance sheet of the issuing bank. The possible risk is in extreme situations when all of these guarantees may be discounted at the same time (Hachem, 2018). By 2019, the size of undiscounted BAs amounted to 11.4 trillion RMB.

Entrusted loans are intercorporate loans with a bank as a serving agent, who earns a serving fee but bears no risk. Using transaction-level data, Allen et al. (2019) investigate two types of entrusted loans 
by listed firms, affiliated loans and non-affiliated loans. In China, listed firms are required by the stock exchanges to disclose the details of the entrusted loans that they make. Affiliated loans are the loans made by a parent firm to a subsidiary or between a customer and a supplier or between business partners in a joint venture and non-affiliated loans are between two parties without such prior relationship. They find that both types of entrusted loans are the market reaction to credit shortage, allowing large listed or state-owned firms with cheap access to capital to channel funds to small-and-medium-sized enterprises. Chen, Ren, and Zha (2018) document the consistent conclusion that entrusted lending tends to be more prevalent when monetary policy is tighter.

Trust financing, intermediated by a trust company, provides funding to a project company at a market interest rate through the issuance of trust WMPs to investors. It is not entirely a new phenomenon in China's financial industry. First introduced in China in 1979 with the establishment of the first trust firm (China International Trust and Investment Corporation, CITIC), the trust industry experienced a period of chaotic development until the enactment of the 'Trust Law' in 2001 as well as the restructuring of the whole industry afterward. The issuance of trust products and other core components of shadow banking such as entrusted loans and bank WMPs rose significantly after the implementation of the Fiscal Stimulus Plan of 2008. Allen et al. (2020) show that the trust industry overtook the insurance industry to become the largest non-banking financial sector in 2012, with total assets amounting to 16.7 trillion RMB by 2015 (23.7\% of the total GDP in 2015). The involvement of banks in the issuance of trust products includes sometimes being the channel for distributing these products as well as introducing their clients to the trust companies. ${ }^{5}$ On some occasions, banks will invest the money they raise through their own WMPs into the trust products of the companies they are introducing. These are referred to as Single Capital Trusts. Other forms of trust products include Collective Investment Trusts, which are standardized products sold to multiple investors and Property Management Trusts, involving the management of non-monetary assets.

Compared to commercial banks, trust companies are lightly regulated. First, in terms of liquidity, banks are subject to the LDR requirement, which was set up to be $75 \%$ and later lifted by the CBRC in late 2015. The lending flow by banks was also closely monitored by the PBoC. Another unconventional policy tool utilized by the $\mathrm{PBoC}$ is 'window guidance'. This type of guidance is in effect a system of informal credit quotas: prescribing both the desired level of credit growth and the sectors the real economy to which this credit should (and should not) be channeled (Allen et al., 2019). At the beginning of 2010, the PBoC started to restrict bank lending to certain areas, especially the real estate industry, in order to curb soaring housing prices. ${ }^{6}$ Second, capital regulation is also different for banks and trust companies. Banks are also subject to capital ratio requirement, with Tier 1 core capital ratio no less than $5 \%$, Tier 1 capital ratio no less than $6 \%$ and capital ratio no less than $8 \%{ }^{7}$ while trust companies were not subject to any capital regulation until 2010, when the CBRC imposed the requirements on net capital. ${ }^{8}$ However, it is difficult to compare the capital regulations for banks and trust

\footnotetext{
${ }^{5}$ In 2008, the CBRC issued guidance (Order 83) to support and set regulatory rules for the cooperation between banks and trust companies, allowing banks to issue loans through off-balance channels such as trust companies. For more details, please see: http://www.gov.cn/gzdt/2008-12/22/content_1184934.htm.

${ }^{6}$ The window guidance is usually reported as part of the PBoC Quarterly Monetary Policy Reports.

${ }^{7}$ In 2008, the CBRC issued Order 1, specifying the capital ratio requirements as well as its calculation. For more details: http://www.gov.cn/gongbao/content/2012/content_2245522.htm.

${ }^{8}$ The CBRC issued Order 5 in 2010, specifying that trust companies should have net capital no less than 200 million RMB, no less than $100 \%$ of the total risk capital, and no less than $40 \%$ of their net assets. Net capital is defined as the net assets minus the deductions of risk assets, minus the risk deductions of contingent liabilities, minus other deductions defined by the CBRC. For more details, please see: http://www.gov.cn/flfg/2010-09/10/content_1699764.htm.
} 
companies, given the definition of net capital of trust companies by the CBRC. Some anecdotal evidence shows that since then, trust companies have largely increased their capital. ${ }^{9}$ The annual financial reports show that during 2011-2015, the average equity ratio for the whole trust industry (68 trust companies in total) is $3.9 \%$, while during the same period, the average equity ratio for listed banks is $6.9 \%$. Third, in terms of reserves, banks are subject to regulations on required reserve ratio, while trust companies are required to draw $5 \%$ of their after-tax profits every year as loss reserve, to a maximum equal to $20 \%$ of the registered capital.

Being lightly regulated, trust companies are the only type of financial institutions that can invest in all the sub-sectors of the capital markets, including the money market, bond market, stock market, credit bank, as well as the real economy in China. In contrast, commercial banks cannot invest directly in the stock market according to the regulation.

\subsection{Pricing of shadow banking products and related risks}

Based on the intricate connection among the banks, nonbanks and capital markets, as well as the relatively light regulation in the shadow banking sector compared to traditional banks, an important question is whether the potential risks have been priced or whether there are neglected risks that might trigger contagion. Recent studies show that the initial pricing of shadow banking products has reflected the underlying risks. Allen et al. (2019) divide entrusted loans into affiliated loans to companies that they are connected to in terms of ownership and non-affiliated loans to companies that they have no ownership connections to. They find that affiliated loans are essentially pass-through loans and the borrowing firms borrow at the same rate as the lending firms, which is roughly the same as the loan rates from the traditional banking system; lenders of nonaffiliated loans use entrusted loans as an alternative investment channel because the growth rate of their main businesses is relatively low. The interest rates for nonaffiliated loans are on average twice as high as official bank loan rates, therefore, lenders of nonaffiliated loans can usually earn immediate profits by acting as credit intermediaries. Further, the authors find that the pricing of nonaffiliated loans reflected the fundamental risks as well as the informational risks of the borrowers. The lending rates increase if the borrower is in a high-risk industry and decrease if it is a state-owned enterprise or if the borrower and lender are in the same industry or located in the same city. The ex-post probability of default also increases with the lending rates. Overall, the evidence suggests that nonaffiliated loans tend to be more market-based transactions and the pricing of these loans is risk-based.

Consistently, the pricing of trust products also relies on the underlying borrowers' risks, the issuing trust companies' risks, as well as the market risk, as shown by Allen et al. (2020). Using product-level data, they find that the initial yield spread is higher if the borrower is from the riskier real estate industry, or located in a province with lower GDP, or if the borrower or issuing trust company is smaller. The product pricing also reflects the market risk that the issuing trust company is exposed to. Using the stock market crash in the summer of 2015 as a negative shock, the authors find that if the trust company has more exposure to the securities markets through issuing more products invested in those areas before the market crash, then the yield spreads of the issued products are significantly higher after the crash.

Shadow banking helps banks circumvent regulations; therefore, a further question is whether the growth of this sector is a source of financial instability. The evidence has been open to debate on this.

${ }^{9}$ As an example of a piece of anecdotal evidence: http://finance.people.com.cn/money/n/2013/1022/c218900-23283695.html. 
In Acharya et al. (2019), the issuing banks of the WMPs take on substantial rollover risks when a large amount of WMPs mature. As the total amount of WMPs rises sharply, the aggregate risk also increases as banks need to roll over greater amounts. During the liquidity crunch in the summer of 2013, when the cost of interbank funds rose unexpectedly, the stock price dropped more for banks with more WMPs maturing in the short run. This indicates that the swift rise of shadow banking has contributed to greater fragility of the financial system. However, from another perspective, given that a large number of borrowers from the shadow banking sector are riskier, if the alternative lenders are better capitalized than banks, the aggregate risk would be mitigated. Allen et al. (2019) provide such evidence. They argue that entrusted loans have the advantage that they are the assets of the lending firms, which have higher equity ratios than banks. The granting of entrusted loans by these firms to risky industries can reduce the likelihood of risk transmission from the riskier real estate sector to the banking system and reduce systemic risks.

\subsection{Implicit guarantees and the role of government}

The possibility of borrowers failing to make loan payments can make implicit and explicit guarantees from either banks or nonbanks, or government attractive to investors. When failures are infrequent and the vast majority of investment products (including bank WMPs and trust products) pay out as expected, any implicit backstop would be highly credible. Allen et al. (2020) argue that a central feature of China's shadow banking sector is the prevalence of such implicit guarantees that investors come to expect on risky investments. They show that implicit guarantees by nonbank financial institutions in an environment with systemic and idiosyncratic risks can be the 'second-best' arrangement in funding risky projects. A key assumption here is that a nonbank financial intermediary has the ability to identify idiosyncratic risks associated with the project and screen out bad projects, while the investors who have capital, do not possess the screening technology. Implicit guarantees also allow the intermediary to retain the flexibility of not paying back in bad economic states. When the future of the nonbank intermediary is uncertain in bad economic states, such flexibility is extremely valuable, compared to explicit guarantees. The latter can lead to the failure of the entity providing the guarantee. Having the intermediary bearing the loss in those extreme bad times can also add stress to the financial system, further creating systemic risks. Empirically, through investigating the investment products issued by trust companies, Allen et al. (2020) also find consistent evidence that the credibility of the implicit guarantees, has been reflected in the ex-ante issuing yield spreads of the trust products. Such implicit guarantees come from either the issuing trust company, or the shareholder of the trust company (central or local government), or the distributing bank. More importantly, strong implicit guarantees flatten the sensitivity of yield spreads to the risks of underlying borrowers.

Huang, Huang, and Shao (2020) focus on the implicit guarantees provided by banks to WMPs that they have issued. They find when the risk perception of a bank increases, the bank extends stronger implicit guarantees to the investors to safeguard its own reputation. When banks face negative shocks, the expense of providing guarantees might erode bank equity and further amply the shocks and increase bank risks.

If there is failure that could trigger market disruption or further systemic risks, the government may intervene. One recent example in China is the crisis of Baoshang bank, a small city commercial bank in Inner Mongolia Province, in May 2019. The crisis originated in the interbank Negotiable Certificate of Deposits wholesale funding market, that Baoshang has been largely exposed to and then spilled over to the WMPs that Baoshang has issued as well as the deposits. Upon the outbreak of the crisis, the $\mathrm{PBoC}$ and $\mathrm{CBRC}$ took over the operations of Baoshang bank. This event illustrates how the Chinese government plays an important, if often implicit, role in backstopping the fragility of the financial 
system. It is also natural to expect that during market turmoil, market participants closer to the center of the government are more likely to obtain support through government intervention. The expectation of government intervention can also lead to risk-seeking activities by creditors, to continue to provide credit at lower costs to entities closer to the government. This can further amply risk in the financial system (Song \& Xiong, 2018). Zhu (2016) provides an extensive description of how government guarantees might have contributed to asset bubbles and speculation in China.

\section{3 | COMPARING TO OTHER COUNTRIES: SHADOW BANKING IN THE EURO AREA, THE United Kingdom AND United States}

As mentioned above, shadow banking is broadly defined as credit intermediation that occurs through activities and entities outside the regulated financial system (Adrian \& Ashcraft, 2012). In the United States, shadow banks intermediate credit through a wide range of securitization and secured funding techniques such as asset-backed commercial paper (ABCP), asset-backed securities (ABS), collateralized debt obligations (CDOs) and repurchase agreements (repos) (Pozsar, Adrian, Ashcraft, \& Boesky, 2012). Before the outbreak of the Subprime Crisis in the United States in 2007, shadow banking provided sources of funding by converting opaque, risky, long-term assets into short-term liabilities with less risk. Such credit creation through credit, maturity and liquidity transformation, significantly reduced the cost of credit relative to direct lending, which further contributed to the asset price appreciation in the real estate market. However, heavy reliance on short-term liabilities to fund illiquid long-term assets made the system more fragile and prone to runs.

Similarly, in the Euro Area, the main components of the shadow banking system include securitization activities, money market funds, repo markets as well as hedge funds. ABCP and ABSs are the most important forms of securitization in Europe. ABSs also account for a large share of the assets held in the Euro Area as collateral for the repo operations of liquidity provision; and the large majority (65\%) of the assets underlying ABSs are loans (Bakk-Simon et al., 2012).

Panel A of Figure 4 plots the change in total assets of shadow banking in China, the Euro Area (8 countries), the United Kingdom and United States over 2006-2018, ${ }^{10}$ using the narrow measure of shadow banking by the Financial Stability Board (FSB), referred to as financial entities that engage in credit intermediation involving liquidity/maturity transformation or leverage. ${ }^{11}$ Although the aggregate growth rate has been slowing around the world, in 2018, the United States still has the largest shadow banking sector, compared to other countries, amounting to 15.2 trillion USD and representing $74.2 \%$ of its GDP and $29.9 \%$ of the total shadow banking assets of the 29 jurisdictions covered by the FSB. The eight participating Euro Area countries comprise the next largest share, with a combined

\footnotetext{
${ }^{10}$ In FSB's monitoring on global shadow banking and nonbank financial intermediation, among the 29 jurisdictions that FSB reports, the eight countries (Belgium, France, Germany, Ireland, Italy, Luxembourg, Netherlands, Spain) in the Euro Area are covered.

${ }^{11}$ Based on the FSB policy framework, the narrow measure of shadow banking includes five types of activities of credit intermediation: management of collective investment vehicles features that make them susceptible to runs (money market funds, fixed-income funds, credit hedge funds, etc.); loan provision dependent on short-term funding (finance companies; leasing/factoring companies, etc.); intermediation of market activities dependent on short-term funding or on secured funding of client assets (broker-dealers, securities finance companies); facilitation of credit creation (credit insurance companies. financial guarantors, etc.); or securitization-based credit intermediation and funding of financial entities (securitization vehicles, structured finance vehicles, etc.). Since the 2018 report, the FSB replaced the term "shadow banking" with "nonbank financial intermediation" (NBFI), to emphasize the forward-looking aspect of the FSB's work.
} 


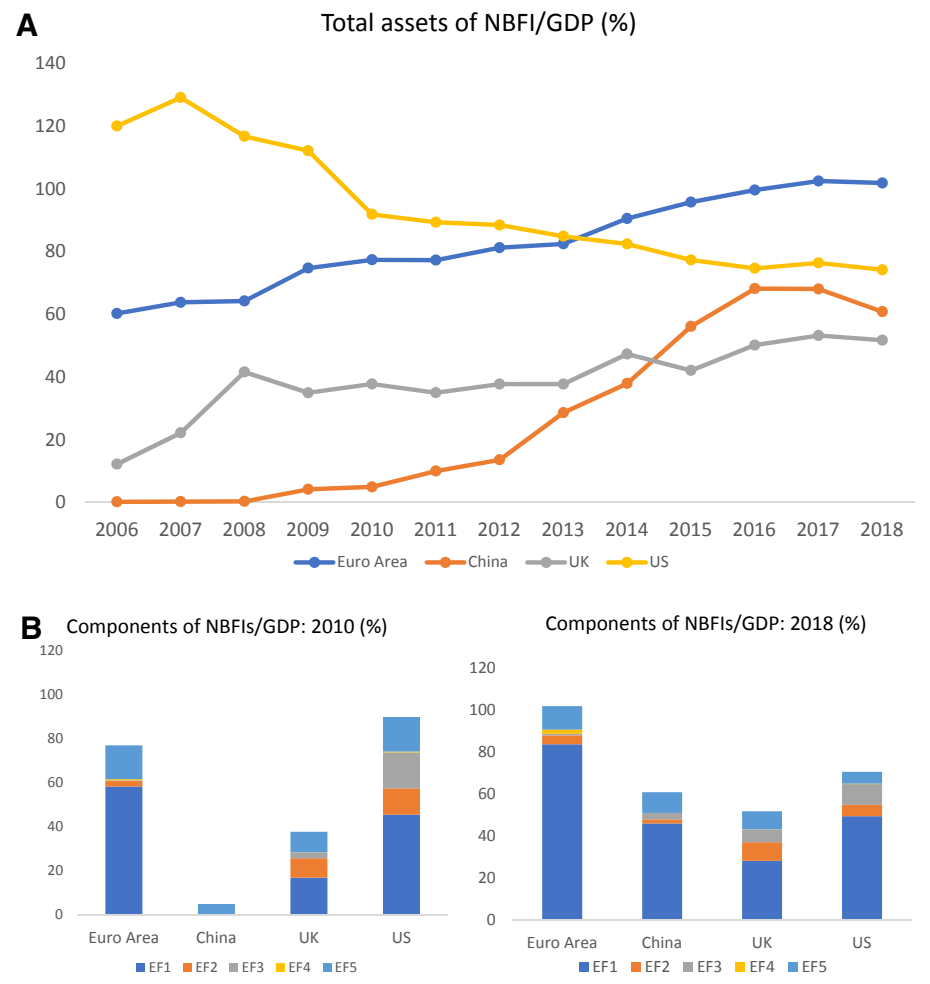

FIGURE 4 Comparing the size of shadow banking: the Euro Area, China, the United Kingdom and United States. Panel A: Size of shadow banking: 2006-2018. This figure plots the total assets of nonbank financial intermediation (narrow measure) over GDP, for the Euro Area (8 countries), China, the United Kingdom and United States, from 2006 to 2018. Among the 29 jurisdictions that the Financial Stability Board (FSB) reports, eight countries (Belgium, France, Germany, Ireland, Italy, Luxembourg, Netherlands, Spain) in the Euro Area are covered. The narrow measure, defined by the FSB Policy Framework, is comprised of nonbank financial institutions that authorities have assessed as being involved in credit intermediation activities that may pose bank-like financial stability risks (i.e., involving maturity/liquidity transformation, leverage or imperfect credit risk transfer) and/or regulatory arbitrage. The narrow measure of NBFIs captures the shadow banking through the exclusion of entities that are not typically part of a credit intermediation chain, or if they are not involved in significant maturity/liquidity transformation and/or leverage. Since the 2018 report, the FSB replaced the term 'shadow banking' with 'nonbank financial intermediation' (NBFI), to emphasize the forward-looking aspect of the FSB's work. Source: FSB, Global Shadow Banking Monitoring Report: 2012-2017; Global Monitoring Report on Non-bank Financial Intermediation: 2018-2019. Panel B: Components of shadow banking: 2010 versus 2018. This figure plots the components of the narrow measure of nonbank financial intermediation (over GDP) for the Euro Area (8 countries), China, the United Kingdom and United States, in 2010 versus 2018. Among the 29 jurisdictions that FSB reports, eight countries (Belgium, France, Germany, Ireland, Italy, Luxembourg, Netherlands, Spain) in the Euro Area are covered. The classification of the components is defined by FSB, using economic functions (EFs): EF1 refers to the management of collective investment vehicles features that make them susceptible to runs (money market funds, fixed-income funds, credit hedge funds, mixed funds, real estate funds); $E F 2$ refers to loan provision dependent on short-term funding (finance companies; leasing/factoring companies, consumer credit companies); $E F 3$ refers to the intermediation of market activities dependent on short-term funding or on secured funding of client assets (broker-dealers, securities finance companies); EF4 refers to the facilitation of credit creation (credit insurance companies, financial guarantors, monolines); EF5 refers to securitization based credit intermediation and funding of financial entities (securitization vehicles, structured finance vehicles, asset-backed securities). Source: FSB, Global Shadow Banking Monitoring Report: 2012-2017; Global Monitoring Report on Nonbank Financial Intermediation: 2018-2019 [Colour figure can be viewed at wileyonlinelibrary.com] 
12.2 trillion USD, $102 \%$ of its GDP and $23.6 \%$ of the total shadow banking assets of the 29 jurisdictions, followed by China, totaling 7.8 trillion USD, 61\% of its GDP and $15.4 \%$ of the total shadow banking assets of the 29 jurisdictions. The shadow banking assets of the United Kingdom amount to 1.4 trillion USD in 2018 and account for 52\% of its GDP. According to FSB statistics, from 2009 to 2018, the narrow measure of shadow banking assets (over GDP) has been growing from $4 . \%$ to $61 \%$ for China, from $35 \%$ to $52 \%$ for the United Kingdom, from $77 \%$ to $102 \%$ for Euro Area (8 countries), while decreasing from $112 \%$ to $74 \%$ for the United States.

Panel B of Figure 4 shows the breakdown of shadow banking in 2010 versus 2018, for the Euro Area, China, the United Kingdom and United States. In 2018, across different countries (regions), the largest component is collective investment vehicles (money market funds, fixed-income funds, credit hedge funds and all types of mixed funds). In the United States, both the intermediation of market activities based on short-term funding or on secured funding and the securitization-based credit intermediation have shrunk significantly in 2018, compared with 2010. In both the United Kingdom and Euro Area, the collective investment vehicles and intermediation on short-term funding and securities funding have increased in 2018, compared to 2010.

A number of recent studies examine shadow banking in the United States (e.g., Acharya, Schnabl, \& Suarez, 2013; Buchak, Matvox, \& Seru, 2018; Gorton \& Metrick, 2010; Irani, Iyer, Meisenzahl, \& Peydro, 2020). Adrian and Ashcraft (2012) provide a review of the evolving literature on this. Although regulatory burden and arbitrage is a common reason behind the rise in shadow banking in the last decade (e.g., Kashyap, Stein, \& Hanson, 2010; Ordonez, 2018; Plantin, 2015), one main difference between China and United States shadow banking is the size of the involving banks (Hachem, 2018). In China, smaller banks engage more in issuing off-balance-sheet WMPs as they are more constrained by liquidity requirements such as LDRs; while in the United States, larger banks went off-balance-sheet, as they are more constrained by capital requirements. For example, Irani et al. (2020) investigate the connection between bank capital regulation and the prevalence of nonbanks in the United States. They find that less-capitalized banks reduce loan intention, particularly loans with higher capital requirements and at times when capital is scarce, with a significant proportion of credit reallocated to nonbanks. ${ }^{12}$

Another difference that the literature has discussed is the role of banks in the growth of shadow banking. The United States shadow banking system is a market-based one and relies on financial engineering to reduce funding costs for firms and create safe assets for investors, while in China, market-based financial instruments or securitization have not been as relevant a factor as in the United States. So far, China's shadow banking is more bank-centric and operates on implicit guarantees by banks as well as government (Dang et al., 2019; Ehlers, Kong, \& Zhu, 2018).

Though the structure of shadow banking and the involvement of financial institutions are unique in China, the challenges this sector brings to the financial system as well as to policy making are similar. For example, Gennaioli, Vishny, and Shleifer (2013) argue that when investors and intermediaries neglect extreme risks, the growth of risky lending by shadow banks might create fragility in liquidity over time. Xiao (2020) finds that monetary tightening could unintentionally increase financial fragility by driving deposits into the uninsured shadow banking sector. D'Avernas, Vandeweyer, and Paries (2020) document that the presence of a sizable shadow banking sector, without access to central bank operations, limits the transmission of monetary policy to asset prices. Consistently, Chen et al. (2018) find the rapid expansion of China's shadow banking dampens the effectiveness of monetary policy in controlling bank credit. Brunnermeier, Sockin, and Xiong (2017) argue that China's liberalized financial system, by loosening regulations on the shadow banking system, prevents the government from experimenting with an easily reversible temporary economic stimulus plan. However, as Allen

${ }^{12}$ But such evidence is only found for larger banks, not for smaller banks with assets fewer than 1 billion USD. 
et al. (2019) argue shadow banking in China can also be beneficial to financial stability as the example of entrusted loans illustrate. By placing the stronger balance sheet of the lending non-financial company in between banks and risky industries such as real estate, financial stability is improved.

\section{I CONCLUDING REMARKS}

Driven by the regulatory burden in the traditional banks as well as the credit constraints in certain restrictive areas, China's shadow banking has grown rapidly in the last decade. Although the regulators have repeatedly attempted to curb the off-balance-sheet activities of banks and impose new regulations on banks and nonbanks, the shadow banking sector has been able to avoid the newly introduced rules and continue growing. The existence of this sector fulfills the high demand for funding, while it may also pose risks to financial stability. It may be neither feasible nor desirable for formal regulatory regimes to eliminate all the risks in the financial system. Implicit guarantees from banks, nonbanks or government might provide a second-best arrangement in funding risky projects and improving welfare where idiosyncratic and systemic risks are possible. Going forward, more research is needed in understanding the balance of market force and government intervention in maintaining the stability of the shadow banking sector, while serving the goal of improving access to finance.

\section{REFERENCES}

Acharya, V. V., Qian, J., Su, Y., \& Yang, Z. (2019). In the shadow of banks: Wealth management products and issuing banks' risks in China. NYU Stern Working Paper. New York: New York University.

Acharya, V., Schnabl, P., \& Suarez, G. (2013). Securitization without risk transfer. Journal of Financial Economics, 107(3), 515-536. https://doi.org/10.1016/j.jfineco.2012.09.004

Adrian, T., \& Ashcraft, A. (2012). Shadow banking regulation. Annual Review of Financial Economics, 4, 99-140. https://doi.org/10.1146/annurev-financial-110311-101810

Allen, F., Gu, X., Li, W., Qian, J., \& Qian, Y. (2020). Implicit guarantees and the rise of shadow banking: The case of trust products. Imperial College London Working Paper. London: Imperial College London.

Allen, F., Gu, X., \& Qian, J. (2018). The people's bank of China: From 1948 to 2016. In R. Edvinsson, T. Jacobson, \& D. Waldenstrom (Eds.), Sveriges riksbank and the history of central banking (pp. 418-453). Cambridge, UK: Cambridge University Press.

Allen, F., Qian, J., \& Gu, X. (2017). An overview of China's financial system. Annual Review of Financial Economics, 9, 191-231. https://doi.org/10.1146/annurev-financial-112116-025652

Allen, F., Qian, M., \& Qian, J. (2005). Law, finance and economic growth in China. Journal of Financial Economics, 77(1), 57-116. https://doi.org/10.1016/j.jfineco.2004.06.010

Allen, F., Qian, Y., Tu, G., \& Yu, F. (2019). Entrusted loans: A close look at China's shadow banking system. Journal of Financial Economics, 133(1), 18-41. https://doi.org/10.1016/j.jfineco.2019.01.006

Bakk-Simon, K., Borgioli, S., Giron, C., Hempell, H., Maddaloni, A., Recine, F., \& Rosati, S. (2012). Shadow banking In the Euro area: An overview. ECB Occasional Paper Series, No. 133. Frankfurt: European Central Bank.

Brandt, L., \& Zhu, X. (2000). Redistribution in a decentralized economy: Growth and inflation in China under reform. Journal of Political Economy, 208(2), 422-451. https://doi.org/10.1086/262124

Brunnermeier, M., Sockin, M., \& Xiong, W. (2017). China's gradualistic economic approach and financial markets. American Economic Review: Papers \& Proceedings, 107(5), 608-613. https://doi.org/10.1257/aer.p20171035

Buchak, G. G., Matvox, T. P., \& Seru, A. (2018). Fintech, Regulatory Arbitrage, And The Risk Of Shadow Banks. Journal of Financial Economics, 130(3), 453-483.

Chen, K., Ren, J., \& Zha, T. (2018). The nexus of monetary policy and shadow banking in China. American Economic Review, 108(12), 3891-3936. https://doi.org/10.1257/aer.20170133

Chen, Z., He, Z., \& Liu, C. (2020). The financing of local government in China: Stimulus loan wanes and shadow banking waxes. Journal of Financial Economics, 137(1), 42-71. 
Cong, L., Gao, H., Ponticelli, J., \& Yang, X. (2019). Credit allocation under economic stimulus: Evidence from China. Review of Financial Studies, 32(9), 3412-3460. https://doi.org/10.1093/rfs/hhz008

D'Avernas, A., Vandeweyer, Q., \& Paries, M. (2020, January). Unconventional monetary policy and funding liquidity risk. ECB Working Paper No. 2350. https://doi.org/10.2139/ssrn.3500556

Dang, T., Liu, L., Wang, H., \& Yao, A. (2019). Shadow banking modes: The Chinese versus US system. Columbia University Working Paper. New York.

Ehlers, T., Kong, S., \& Zhu, F. (2018, February). Mapping shadow banking in China: Structure and dynamics. BIS Working Paper No. 701.

Gennaioli, N., Shleifer, A., \& Vishny, R. W. (2013). A model of shadow banking. Journal of Finance, 68(4), 1331-1363. https://doi.org/10.1111/jofi.12031

Gorton, G., \& Metrick, A. (2010). Regulating the shadow banking system. Brookings Papers on Economic Activity, 2 , 261-297.

Hachem, K. (2018). Shadow banking in China. Annual Review of Financial Economics, 10, 287-308.

Hachem, K., \& Song, Z. (2017). Liquidity rules and credit booms. Chicago Booth Working Paper.

Huang, J., Huang, Z., \& Shao, X. (2020). The rise of implicit guarantees: Evidence from shadow banks in China. Working Paper.

Irani, R., Iyer, R., Meisenzahl, R., \& Peydro, J. (2020). The rise of shadow banking: Evidence from capital regulation. Imperial College London Working Paper.

Kashyap, A., Stein, J., \& Hanson, S. (2010). An analysis of the impact of "substantially heighted" capital requirements on large financial institutions. Harvard Working Paper.

Moody's. (2020, March). Quarterly China shadow banking monitor. New York: Moody's Investor Service.

Ordonez, G. (2018). Sustainable shadow banking. American Economic Journal: Macroeconomics, 10(1), 33-56. https:// doi.org/10.1257/mac. 20150346

Plantin, G. (2015). Shadow banking and bank capital regulation. Review of Financial Studies, 28(1), $145-175$.

Pozsar, Z., Adrian, T., Ashcraft, A., \& Boesky, H. (2012). Shadow banking. Federal Reserve Bank of New York Staff Report, No. 458.

Song, Z., \& Xiong, W. (2018). Risks in China's financial system. Annual Review of Financial Economics, 10, $261-286$. Wang, H., Wang, H., Wang, L., \& Zhou, H. (2019). Shadow banking: China's dual-track interest rate liberalization. Working Paper.

Xiao, K. (2020). Monetary transmission through shadow banks. Review of Financial Studies, 33(6), 2379-2420.

Zhu, N. (2016). China's Guaranteed Bubble: How Implicit Government Support Has Propelled China's Economy While Creating Systemic Risk. New York: McGraw-Hill Education.

How to cite this article: Allen F, Gu X. Shadow banking in China compared to other countries. The Manchester School. 2021;89:407-419. https://doi.org/10.1111/manc.12331 